•综述・

\title{
中国纳入一级保护的极小种群野生植物濒危机制
}

\author{
姚志 ${ }^{1,2}$, 郭军 ${ }^{2}$, 金晨钟 ${ }^{2 *}$, 刘勇波 $112^{*}$
}

1. 中国环境科学研究院国家环境保护区域生态过程与功能评估重点实验室，北京 100012; 2. 湖南人文科技学院农田杂草防控技术与应用 协同创新中心, 湖南娄底 417000

摘要: 为科学有效地保护极小种群野生植物, 明确其濒危机制具有重要意义。本文通过分析中国28种极小种群一级保护野生 植物的种群特征及其濒危的内在原因和受威胁因素等, 总结了极小种群野生植物的濒危机制。极小种群野生植物的种群特征 表现为遗传多样性低(13种)、衰退型种群结构(11种)、聚集型分布(11种)且分布区域狭窄(20种)。极小种群野生植物濒危的内 在原因主要是繁殖力低(21种)和竞争能力弱(16种)。受威胁因素主要包括过度采挖等人类活动导致的种群数量减少(15种)和生 境破坏(25种)以及气候变化等。因此, 除了保护极小种群野生植物免遭人类活动破坏, 保护策略应加强关注种群规模的维持 和遗传多样性的保护。

关键词: 极小种群野生植物; 种群特征; 濒危机制; 人为干扰; 保护遗传多样性

姚志，郭军，金晨钟，刘勇波 (2021) 中国纳入一级保护的极小种群野生植物濒危机制. 生物多样性, 29, 394-408. doi: 10.17520/biods.2020316.

Yao Z, Guo J, Jin CZ, Liu YB (2021) Endangered mechanisms for the first-class protected Wild Plants with Extremely Small Populations in China. Biodiversity Science, 29, 394-408. doi: 10.17520/biods.2020316.

\section{Endangered mechanisms for the first-class protected Wild Plants with Extremely Small Populations in China}

Zhi Yao ${ }^{1,2}$, Jun $\mathrm{Guo}^{2}$, Chenzhong $\mathrm{Jin}^{2 *}$, Yongbo Liu ${ }^{\circledR 1,2^{*}}$

1 State Environmental Protection Key Laboratory of Regional Eco-process and Function Assessment, Chinese Research Academy of Environmental Sciences, Beijing 100012

2 Hunan Provincial Collaborative Innovation Center for Field Weeds Control, Hunan University of Humanities, Science and Technology, Loudi, Hunan 417000

\section{ABSTRACT}

Aims: It is important to clearly identify the mechanisms that leads Wild Plants with Extremely Small Populations to become endangered as a way to effectively protect these WPESP.

Progresses: Here, we review the population characteristics, internal causes, and external threat factors for the first-class protected WPESP (28 species in China) and accordingly discuss the mechanisms leading to plants becoming endangered. Most WPESP displayed at least one of four population characteristics that likely resulted in their current endangered status. First, 20 WPESP species (such as Parakmeria omeiensis, Abies beshanzuensis and Cycas changjiangensis) had a narrow distribution area. Combining a narrow distribution area with low fertility and weak competitive capacity as intrinsic factors results in WPESP species to become endangered. Second, the distribution structure for 11 WPESP species was aggregated (e.g., Abies ziyuanensis, Kmeria septentrionalis, Metasequoia glyptostroboides). Third, there was declining population structures for 11 WPESP (e.g., Thuja sutchuenensis, Metasequoia glyptostroboides, Pinus squamaia). This declining population structure has a negative role in maintaining stable population growth. The fourth population characteristic was that the genetic diversity of 13 WPESP species (46\%) was low (e.g., Manglietia decidua, Abies yuanbaoshanensis, Cycas debaoensis). Low genetic diversity is unfavorable for these species to adapt to a changing environment and leads them to face risks of extinction. Twenty-one WPESP species (75\%) exhibited low fertility, such as Acer yangjuechi and Abies beshanzuensis. The poor seed quality and low yield of WPESP species leads to a difficult regeneration of populations. The competitive capacity of 57\%

收稿日期: 2020-08-07; 接受日期: 2020-10-15

基金项目: 生态环境部生物多样性调查与评估项目(2019HJ2096001006)

* 共同通讯作者 Co-authors for correspondence. E-mail: liuyb@craes.org.cn; hnldjcz@sina.com 
WPESP species (16) is relatively weak (e.g., Shaniodendron subaequale and Cathaya argyrophylla), which decreases growth and reproduction for these species. External factors that threaten WPESP mainly include overexploitation decreasing abundance (15 species), human activities and natural disasters destroying habitats (25 species), and geological movements plus climate change affecting the survival of WPESP.

Prospects: In addition to protecting WPESP against destruction from human activities, conservation strategies should focus on the maintenance of population size and the conservation of genetic diversity of WPESP.

Key words: Wild Plants with Extremely Small Populations (WPESP); population characteristics; endangered mechanism; human disturbance; conservation of genetic diversity

中国受威胁植物有3,000多种(覃海宁等, 2017), 其中分布区域狭窄或呈间断分布的野生植物被定 义为“极小种群野生植物” (藏润国等, 2016; Yang et al, 2020)。极小种群野生植物长期受外界因素胁迫 干扰, 种群呈现衰退和数量持续减少趋势, 种群及 个体数量极少, 有些已经低于稳定存活界限的最小 可存活种群, 随时面临灭绝的风险 (Ren et al, 2012)。极小种群野生植物多为中国特有植物, 在生 态和经济上具有重要价值(Ma et al, 2013)。如果不 及时保护, 其潜在的基因价值和生物特征就会随物 种的绝灭而消失(张则瑾等, 2018)。因此, 明确极小 种群野生植物濒危机制, 提高保护成效, 有助于维 持生态平衡和促进生态可持续发展, 对我国的生物 多样性保护具有重要意义(Guisan et al, 2013; 张则 瑾等, 2018)。

极小种群野生植物的物种濒危机制研究已从 单一的种群生态学和群体遗传学研究发展成多学 科交叉的综合性研究, 并取得了令人鼓舞的进展 (Aguilar et al, 2006; Lowe et al, 2017)。《全国极小种 群野生植物拯救保护工程规划》确定了首批120种 重点保护的极小种群野生植物(Ren et al, 2014)。其 中, 中国特有的纳入一级保护的极小种群野生植物 有33种(http://www.iplant.cn/rep/protlist)。经检索, 目 前暂时没有关于玉龙构兰(Cypripedium forrestii)、丽 江构兰 (C. lichiangense) 、斑 叶枸兰 (C. margaritaceum)、小花构兰(C. micranthum) 和昌江石 斛(Dendrobium changjiangense)等5种特有极小种群 野生植物的研究报道。故本文将讨论和分析 28 种极 小种群野生植物的特征及濒危因素, 拟为制定极小 种群植物的保护对策提供科学依据。从检索到的 783 篇关于这28种极小种群野生植物的文献中, 选 取具有详细分布区域和种群特征的138篇研究性文 章。从物种的分布地点可以发现, 这28种极小种群 野生植物主要集中分布在我国南方(图1), 具有明显
的分布区域狭窄特征。

\section{极小种群野生植物的种群特征}

\section{1 种群规模小}

种群规模小是极小种群野生植物的主要特征, 有 15 种的种群规模小于 1,000 株(表1), 例如猪血木 (Euryodendron excelsum) 、天目铁木 (Ostrya rehderiana)、云南蓝果树(Nyssa yunnanensis)等。百 山祖冷杉(Abies beshanzuensis)野生存活数量只有3 株, 是世界上最为濒危的12种植物之一(Zhu et al, 2019); 普陀鹅耳枥(Carpinus putoensis)是极小种群 野生植物中现存野生植株最少的物种之一, 仅存1 株, 有“地球独子”之称(Sheng \& Zhu, 2018)。虽然有 10 个物种的个体数量和种群数量较多, 但多数个体 都聚集在一个或两个种群中; 其他18个物种种群规 模小, 增加了消失的风险。例如瑶山苣苔 (Dayaoshania cotinifolia), 除了 2 个 40 株以上的较大 种群外, 大部分为 10 株以下的小种群(王玉兵等, 2008); 在德保苏铁(Cycas debaoensis)的15个种群中, 除了扶平种群为 800 株左右外, 其余种群规模都不 足10株, 其中平泮种群与下泮种群个体数量分别只 有2株和6株, 具有消失的风险 (王超红, $2007^{\circledR}$; 潘光 波和赵峰否, 2011)。

\section{2 种群多为零星或岛状狭域分布}

根据28种极小种群野生植物已有的地理分布 现状, 崖柏(Thuja sutchuenensis)、百山祖冷杉、峨 眉拟单性木兰(Parakmeria omeiensis)等20个物种呈 零星或岛状的狭域分布(表1)。例如葫芦苏铁(Cycas changjiangensis)仅分布在海南省昌江县坝王岭约 $70 \mathrm{~km}^{2}$ 的狭小范围内(简曙光等, 2005); 百山祖冷杉 现存野生植株仅3株, 占地面积不足 $2 \mathrm{~km}^{2}$ (Zhu et al, 2019); 巧家五针松(Pinus squamaia)只分布在云南

(1) 王超红 (2007) 德保苏铁居群生物学及其保护生物学研究. 硕士学位 论文, 广西师范大学, 广西桂林. 


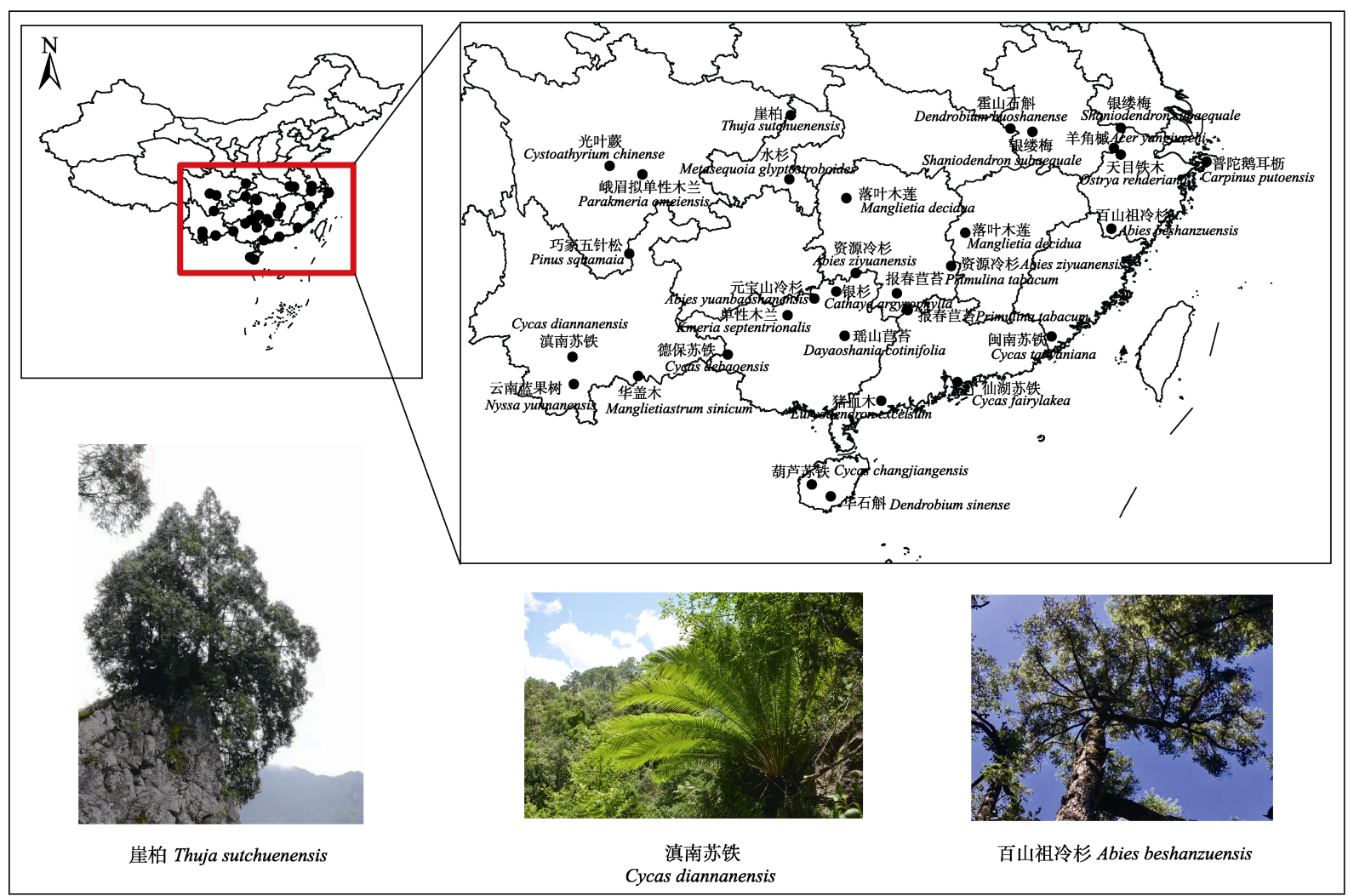

图127种极小种群野生植物地理分布图(灰干苏铁无分布点数据)。崖柏图片由姚志提供, 滇南苏铁图片由龚洵提供, 百山祖 冷杉图片由向巧萍提供。

Fig. 1 Distribution of 27 Wild Plants with Extremely Small Populations (No distribution data of Cycas hongheensis). The picture of Thuja sutchuenensis is provided by Zhi Yao, Cycas diannanensis is provided by Xun Gong, and Abies beshanzuensis is provided by Qiaoping Xiang.

东北部巧家县新华镇杨家湾一个山脊的东西两个 坡面上, 分布面积仅 $5 \mathrm{~km}^{2}$ (1)

\section{3 种群呈聚集型分布格局}

在28种极小种群野生植物中, 种群分布格局呈 聚集型的有资源冷杉(Abies ziyuanensis)、单性木兰 (Kmeria septentrionalis) 、水杉 (Metasequoia glyptostroboides)等11种(表1), 不利于种群的维持和 发展。有些物种的分布格局在不同生长阶段和生境 条件下会表现出差异, 例如元宝山冷杉(Abies yuanbaoshanensis)在幼苗、幼树阶段为聚集分布, 中 龄阶段向随机分布发展, 大树呈均匀分布(李先琨 等, 2002a); 银杉(Cathaya argyrophylla)在银杉一亮 叶青冈(Cyclobalanopsis phanera)林中为典型的聚集 分布, 而在银杉一甜槠(Castanopsis eyrei)林中因个 体数量不均衡死亡而出现随机分布的格局(谢宗强,

(1) 陶翠 (2013) 中国五针松组濒危植物的濒危机制探究. 硕士学位论文, 北京林业大学, 北京.
1999)。

\section{4 极小种群野生植物遗传多样性低}

有13种极小种群野生植物的遗传多样性较低, 这些物种对环境的适应力较差, 影响了物种的进化 潜力(表1)。例如，廖文芳等(2004)利用ISSR分子标 记研究落叶木莲(Manglietia decidua)的遗传多样性, 并与同科的其他物种以及其他特有植物的遗传多 样性进行了比对, 发现落叶木莲的遗传多样性极低 (Nei’s 基因多样性 0.0637, Shannon多样性指数 0.0936, 多态位点百分率17.28\%); 王燕等(2004)使 用AFLP分子标记方法, 发现元宝山冷杉种群的遗 传多样性较低(Nei’s基因多样性0.1510, Shannon多 样性指数 0.1735 , 多态位点百分率 $50.96 \%$ )。

一般认为濒危植物的遗传多样性水平较低, 但 仙湖苏铁(Cycas fairylakea)、猪血木、崖柏等7个极 小种群野生植物的遗传多样性较高(表1)。例如, 王 晓明等(2006)应用ISSR分子标记研究了仙湖苏铁野 


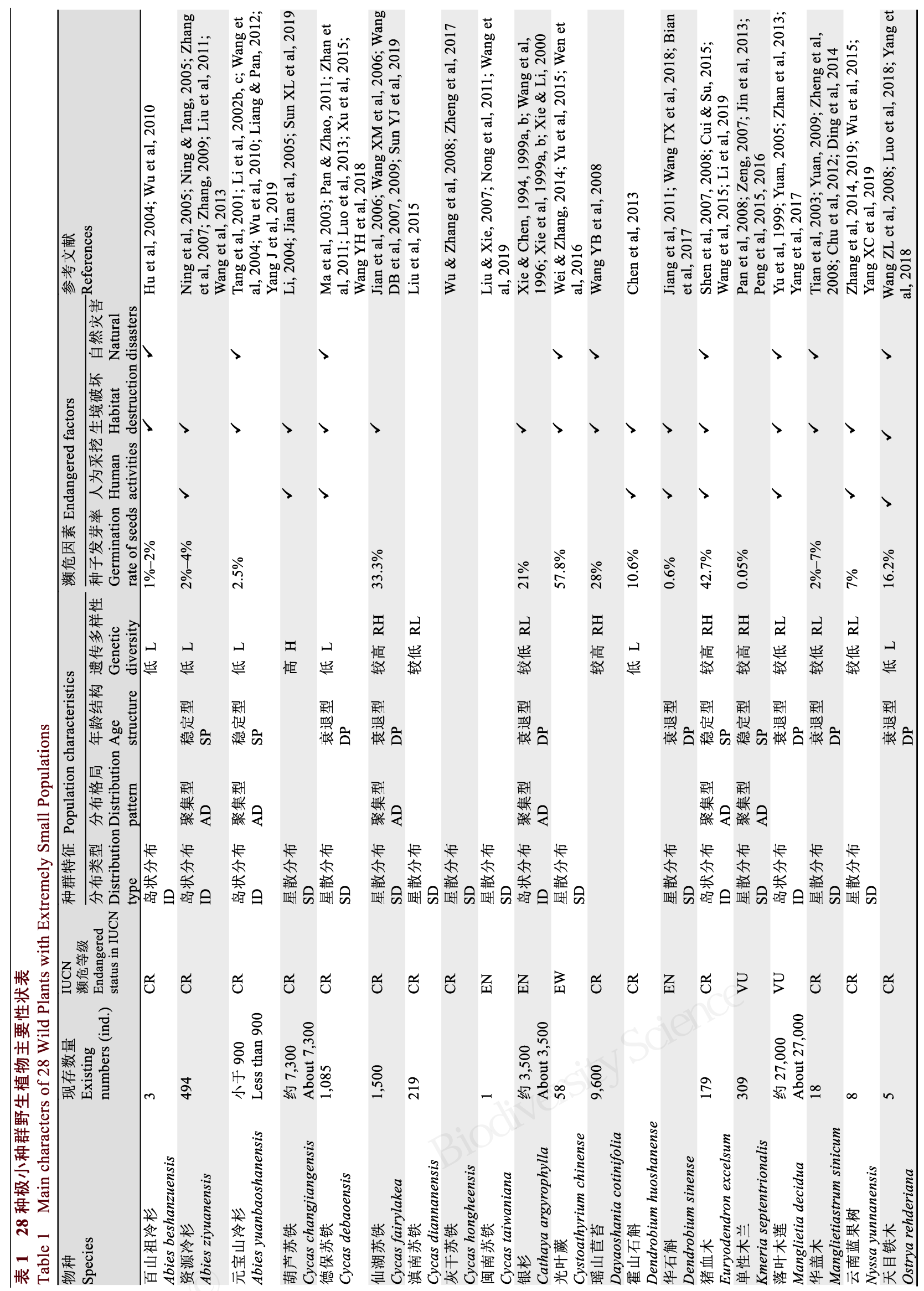




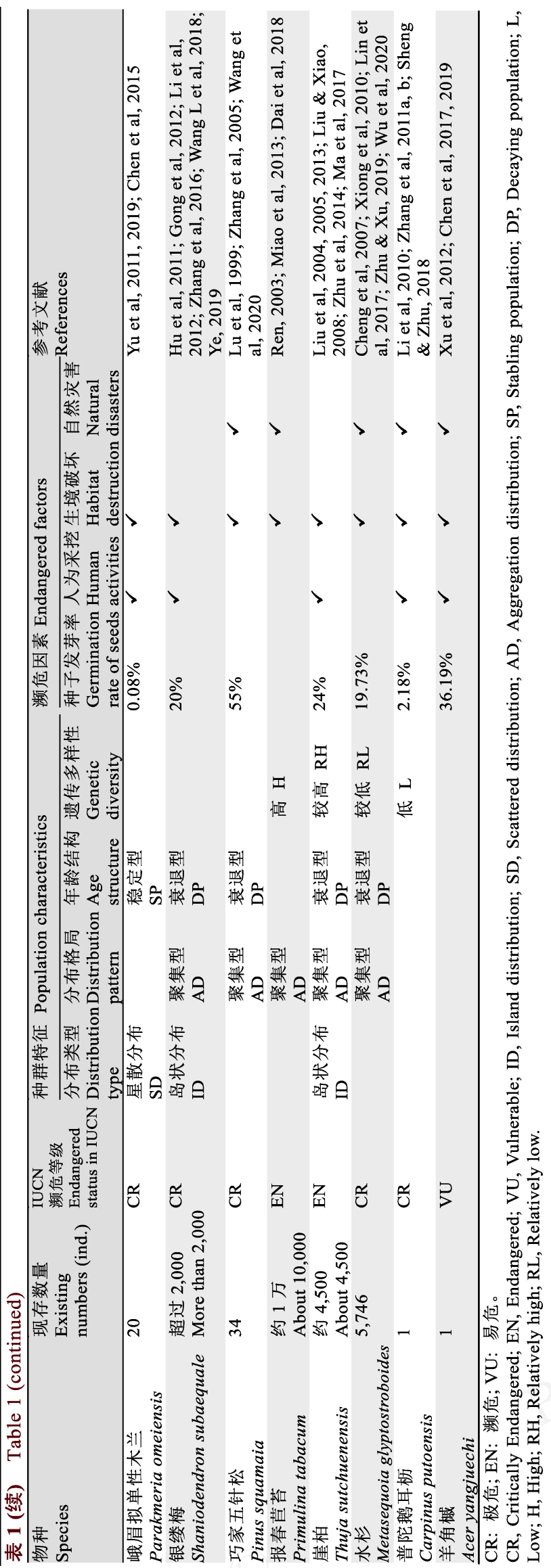

生种群遗传多样性, 发现其遗传多样性高于其他苏 铁类植物和濒危植物 (Nei’s 基因多样性 0.2196, Shannon多样性指数 0.3445 , 多态位点百分率 87.01\%); 张仁波等(2007)采用RAPD分子标记对崖 柏天然种群遗传多样性进行研究, 发现崖柏种群的 遗传多样性与其他濒危植物相比较为丰富(Nei's基 因多样性 0.3015 , Shannon多样性指数 0.4360 , 多态 位点百分率72.09\%), 表明遗传多样性不是造成这 些物种濒危的首要因素, 反而是人类活动和生境破 坏等因素导致其面临较高的灭绝风险(刘建锋和肖 文发, 2008; 苏金源等, 2020)。

\section{5 种群结构多为衰退型}

在28种极小种群野生植物中, 德保苏铁、崖柏、 水杉等11个物种的种群年龄结构表现为衰退型(表 1), 即幼龄个体少而老龄个体多、死亡率大于萌发 率等, 这种种群结构由于难以维持种群增长可能会 导致种群灭绝。例如因幼龄个体存活率较低, 导致 水杉种群幼龄个体不断减少, 老龄个体逐渐增加, 难以维持种群整体的长期稳定(林勇等, 2017); 银 缕梅(Shaniodendron subaequale)种群年龄结构差异 较大, 大部分种群缺乏幼龄个体, 各个年龄段都有 着较高的死亡率, 有些种群衰退严重(龚滨等, 2012)。

\section{2 导致极小种群野生植物濒危的因素}

\section{1 繁殖力低使种群更新缓慢}

在自然条件下, 物种濒危的关键环节是种子 向幼苗的转化过程, 这个过程涉及果实成熟、种子 萌发等, 没有足够数量的幼苗, 种群就难以更新。 有 21 种濒危植物的种子品质差且产量很少(表1), 导致种子向幼苗的转化率较低, 形成的幼苗数量 较少 (1)(2)(4)。百山祖冷杉野生植株仅有3株, 人工繁 育的后代能结实嫁接的植株也不多, 种子发芽率仅 有 1\%-2\% (吴友贵等， 2010); 羊角槭 (Acer yangjuechi) 种子内没有胚乳, 饱满种子生活力仅有 20.53\%, 在其果实生长期间, 果序脱落率高达

(1) 哀建国 (2005) 百山祖冷杉濒危机制与保护对策研究. 硕士学位论文, 浙江大学, 杭州.

(2) 翟月婷 (2010) 霍山石斛试管丛生芽及原球茎继代增殖措施的研究. 硕士学位论文, 安徽农业大学, 合肥.

(3) 许小连 (2012) 濒危植物羊角械生殖生物学的初步研究. 硕士学位论 文, 浙江农林大学, 杭州.

(4) 付迪 (2019) 珍稀濒危植物天目铁木的生殖生物学研究. 硕士学位论 文, 杭州师范大学, 杭州. 
$67.7 \%$, 落果率高达 $87.3 \%$, 而且果实败育率高(石 柏林等, 2006; 肖志成和高捍东, 2008), 这些特征均 导致种群更新缓慢。

\section{2 种间竞争能力差}

物种在群落内的竞争能力差, 获得资源就少, 从而直接或间接地影响其生长发育。有 16 种极小种 群野生植物在种间竞争中处于不利地位, 多表现为 生长缓慢(表1) (莫耐波等, 2012; 陶翠, 2013 ${ }^{\circledR}$; 王金金 等, 2017)。银杉由于对光的需求大, 只有在群落的 林窗内光照充足的条件下其幼苗才有机会发展, 当 它们进入成年期后, 在群落竞争中则处于不利地位 (谢宗强等, 1998, 谢宗强和陈伟烈, 1999a, b); 银缕 梅与青冈(Cyclobalanopsis glauca)和其他阔叶树种 之间的生态位重叠程度较高, 在争夺光照、水分、 土壤养分时处于弱势, 导致其在群落中居于次要和 从属地位(方顺清等, 2004; 黄绍辉等, 2006)。

\section{3 极小种群野生植物的受威胁因素}

\section{1 动物取食影响极小种群野生植物种群更新}

动物取食野生植物的叶片、果实、种子等不仅 影响植物的生长发育, 也阻碍了种群的更新(表1) (潘光波和赵峰磊, 2011; 梁凌林和潘庆宝, 2012; 赵 燕, 2018)。例如, 鼠类在单性木兰种子散播初期至 种子萌发期均有取食现象, 包括地表和土壤中的种 子, 导致单性木兰天然更新过程中由种子转化成幼 苗时存在严重障碍(赖家业等, 2007; 潘春柳等, 2008); 银杉球果产量很少, 成熟后被昆虫、鸟类、 哺乳类动物取食达到15\%, 落到地表的种子几乎全 被鸟类和鼠类取食, 只有埋于土壤较深层 $(3 \mathrm{~cm}$ 以 下)的种子才得以保留, 存活种子数量极小, 成为银 杉种群更新的主要障碍(谢宗强等, 1998; 谢宗强和 陈伟烈, 1999a; 谢宗强和李庆梅, 2000)。

\section{2 人为过度采挖和砍伐降低种群规模}

在28种极小种群野生植物中, 有15种由于经济 价值、观赏价值和商业价值高而被人为大量采挖和 砍伐, 直接导致数量快速减少, 成为其濒危的直接 因素(表1)。例如崖柏因木材质地坚硬而长期被砍伐 用作建筑材料, 现在重庆城口县的建筑中仍能发现 用于建筑材料的崖柏木材 (Guo et al, 2019)。德保苏 铁由于具观赏性而有较高的经济价值, 被当地居民

(1) 陶翠 (2013) 中国五针松组濒危植物的濒危机制探究. 硕士学位论 文, 北京林业大学, 北京.
肆意采挖, 导致其数量从2001年的2,200多株锐减 到2010年的1,100多株, 特别是成年德保苏铁的数 量减少更为严重(潘光波和赵峰否, 2011; 农安, 2014)。

\section{3 人为开发利用破坏极小种群野生植物的生境}

工程建设、旅游开发和过度艮荒等因素破坏了 24种极小种群野生植物生存的原有生境(表1), 具体 表现为生境破碎化或面积变小, 从而使得种群规模 减小。瑶山菅苔由于人为活动对其原生境的破坏, 个体数由1999年的9,600株锐减到2006年的1,000株 左右，减少了近 $90 \%$ (王玉兵等，2008)。灰干苏铁 (Cycas hongheensis) 2020年的个体数量比1992年减 少了 $47 \%$; 水杉原生种群母树由 1983 年的 5,779 株减 少至2003年的5,393株(王希群等, 2005; 程丹丹等, 2007)。

\section{4 气候变化和自然灾害威胁物种的生存}

气候变化和自然灾害等严重威胁物种的生存, 迫使它们或者改变自身性状以适应环境, 或者迁移 到其他适生区域。在28种极小种群野生植物中有 15 种子遗植物(表1) (李晓笑, 2013 ${ }^{(2)}$; Zhu et al, 2019; 邓莎等, 2020), 这些物种在经历过晚第三纪气候变 冷以及第四纪冰期的影响后, 世代周期变长, 繁殖 能力降低, 如银杉、崖柏、资源冷杉等。崖柏由 260 万年前的山西榆社盆地南迁到现存分布区一大 巴山山区, 该区温暖湿润的气候条件对崖柏起到了 “避难所”的作用(陈冬梅等, 2011; 邱迎君等, 2011; Cui et al, 2015)。现存的5株天目铁木中, 有一株高 $7 \mathrm{~m}$ 、有300多年寿命的植株主干顶部遭受过雷击(管 康林和陶银周, 1988); 百山祖冷杉生长在水沟边, 曾在 20 世纪60年代被大水冲倒一株 ${ }^{3}$; 瑶山菅苔在 2008年由于冻害而导致直接死亡的有100多株(王玉 兵等, 2008)。

\section{4 极小种群野生植物的濒危机制}

基于前文对 28 种极小种群野生植物的种群和 个体特征以及受威胁因素分析, 发现导致其濒危的 原因有 4 个。(1)在种群尺度上, 衰退型种群结构和聚 集狭域分布特征是导致其濒危的原因之一, 这使得

(2) 李晓笑 (2013) 中国 5 种冷杉属植物生态濒危机制研究. 硕士学位论 文, 北京林业大学, 北京.

(3) 哀建国 (2005) 百山祖冷杉濒危机制与保护对策研究. 硕士学位论文, 浙江大学, 杭州. 
其遗传多样性过低, 从而对环境的适应力和进化潜 力降低, 进一步提高了濒危的风险。(2)在个体尺度 上, 大多数极小种群野生植物的种子品质差且产量 少, 繁育力低, 形成的幼苗数量少, 导致种群变小 且难以更新; 加上极小种群野生植物在种间竞争中 处于弱势地位, 直接或间接影响其生长发育, 进一 步影响了种群大小。(3)人为过度采挖、自然灾害等 因素导致个体数量降低, 工程建设、旅游开发和过 度垦荒等导致的生境破坏或消失使得野生植物种 群数量减少, 是极小种群野生植物濒危的主要原 因。(4)宏观尺度的全球气候变化等是导致极小种群 野生植物濒危的历史原因。

\section{保护建议}

极小种群野生植物因其分布地域狭窄、种群衰 退严重, 个体数量低于其稳定存活界限, 是急需优 先拯救的国家重点保护濒危植物。优先保护极小种 群野生植物有助于延缓物种多样性的流失、维护生 态平衡以及促进生态可持续发展, 对我国生物多样 性保护具有重要意义。就地保护是其保护的主要措 施之一(张文辉等, 2002; Kramer et al, 2008), 在必 要时候建立保护区或植物园, 对种质和生物资源进 行迁地保护是全球植物保护战略的重点(Larkin et al, 2016)。

在就地保护和迁地保护措施的基础上，基于 28 种极小种群野生植物的濒危机制分析，我们建议: (1)对自身繁育力低的极小种群野生植物, 开展人工 繁育并加强野外回归工作, 提高种群的自我更新能 力(Ren et al, 2014); (2)修复栖息地内破坏的生态系 统, 提高群落生态系统的稳定性, 改善其生境条件; (3)除了采取措施增加个体数量之外, 应加强对极小 种群野生植物的种群结构和遗传多样性的研究, 保 护整个种群的遗传多样性。

\section{ORCID}

刘勇波 (D) https://orcid.org/0000-0003-1618-8813

\section{参考文献}

Aguilar R, Ashworth L, Galetto L, Aizen MA (2006) Plant reproductive susceptibility to habitat fragmentation: Review and synthesis through a meta-analysis. Ecology Letters, 9, 968-980.

Bian ZX, Yan CY, Yao XJ, Yang FS (2017) Determination of seed viability in endangered orchid of Dendrobium sinense. Chinese Journal of Tropical Crops, 38, 403-407. (in Chinese with English abstract) [边子星, 颜彩燕, 姚肖健, 杨福孙 (2017) 濒危华石斛种子活力测定方法研究. 热带作物学 报, 38, 403-407.]

Chen CW, Dai J, Yao HJ, Han BX, Chen NF (2013) Research progress on resources and identification of Dendrobium huoshanense. Research and Practice on Chinese Medicines, 27(3), 84-87. (in Chinese) [陈存武, 戴军, 姚厚军, 韩邦 兴, 陈乃富 (2013) 霍山石斛资源与鉴定研究进展. 现代 中药研究与实践, 27(3), 84-87.]

Chen DM, Kang HZ, Liu CJ (2011) An overview on the potential Quaternary glacial refugia of plants in China mainland. Bulletin of Botanical Research, 31, 623-632. (in Chinese with English abstract) [陈冬梅, 康宏樟, 刘春江 (2011) 中国大陆第四纪冰期潜在植物避难所研究进展, 植物研究, 31, 623-632.]

Chen J, Fan JC, Lu CT, Zhao B (2015) Biological characteristics and conservation measures of endangered species of Parakmeria omeiensis. Science and Technology of Sichuan Agriculture, (4), 22-25. (in Chinese) [陈娟, 范 继才, 卢昌泰, 赵波 (2015) 濒危树种峨眉拟单性木兰的 生物学特征及保育措施. 四川农业科技, (4), 22-25.]

Chen XB, Liu Y, Zhao MS, Tu SP (2017) Embryo development and dormancy releasing of Acer yangjuechi, the extremely endangered plant. Scientia Silvae Sinicae, 53(4), 65-73. (in Chinese with English abstract) [陈香波, 刘杨, 赵明水, 涂淑萍 (2017) 极度濒危树种羊角槭的种 胚发育与休眠解除. 林业科学, 53(4), 65-73.]

Chen XB, Lü XL, Liu Y, Zhao MS, Cui XH, Zhang DM (2019) Floral morphology and flowering process of Acer yangjuechi, the extremely endangered plant. Bulletin of Botanical Research, 39, 329-337. (in Chinese with English abstract) [陈香波, 吕秀立, 刘杨, 赵明水, 崔心红, 张冬 梅 (2019) 极度濒危树种羊角棫花部形态特征及开花动 态. 植物研究, 39, 329-337.]

Cheng DD, Ge JW, Lai XL, Liu XQ, Fan SH (2007) Status and conservation strategy of native population of Metasequoia glyptostroboides. Environmental Science \& Technology, 30(5), 48-50, 118. (in Chinese with English abstract) [程丹 丹, 葛继稳, 赖旭龙, 刘宪群, 范深厚 (2007) 原生水杉 种群的现状及其保护对策. 环境科学与技术, 30(5), $48-50,118$.

Cui LM, Su YJ (2015) SSR markers for a critically endangered species Euryodendron excelsum and a distantly related species Ternstroemia gymnanthera (Ternstroemiaceae). Biochemical Systematics and Ecology, 58, 288-292.

Cui YM, Sun B, Wang HF, Ferguson DK, Wang YF, Li CS, Yang J, Ma QW (2015) Exploring the formation of a disjunctive pattern between eastern Asia and north America based on fossil evidence from Thuja (Cupressaceae). PLoS ONE, 10, e0138544.

Chu YX, Li F, Ouyang ZQ (2012) Cutting propagation 
techniques of Managlietastram sinicum. Forest Inventory and Planning, 37(1), 128-130. (in Chinese with English abstract) [楚永兴, 李帆, 欧阳志勤 (2012) 华盖木扞插育 苗技术. 林业调查规划, 37(1), 128-130.]

Dai WT, Miao SY, Tao WQ, Li CB, Zhao XJ (2018) Plant diversity of key national protected species Primulina tabacum distribution area. Chinese Wild Plant Resources, 37(3), 64-67, 75. (in Chinese with English abstract) [戴文 坛, 缪绅裕, 陶文琴, 李春波, 赵新建 (2018) 国家保护 植物报春苣苔分布地的植物多样性研究. 中国野生植物 资源, 37(3), 64-67, 75.]

Deng S, Wu YN, Wu KL, Fang L, Li L, Zeng SJ (2020) Breeding characteristics and artificial propagation of 14 species of Wild Plant with Extremely Small Populations (WPESP) in China. Biodiversity Science, 28, 385-400. (in Chinese with English abstract) [邓莎, 吴艳妮, 吴坤林, 房 林, 李琳, 曾宋君 (2020) 14种中国典型极小种群野生植 物繁育特性和人工繁殖研究进展. 生物多样性, 28 , 385-400.]

Ding JY, Yuan CM, Cao MM, Liu WW, Yu C, Zhang HY, Zhang Y, Di YT, He HP, Li SL, Hao XJ (2014) Antimicrobial constituents of the mature carpels of Manglietiastrum sinicum. Journal of Natural Products, 77, 1800-1805.

Fang SQ, Yan JF, Weng Q, Huang SH (2004) Population ecological status quo and protection study on Shaniodendron subaequale M. B. Deng, H. T. Wei in Longchi Mountain Reserve in Yixing. Journal of Jiangsu Forestry Science \&Technology, 31(2), 4-5, 11. (in Chinese with English abstract) [方顺清, 颜建法, 翁琴, 黄绍辉 (2004) 宜兴龙池山自然保护区银缕梅种群生态现状及保 护研究. 江苏林业科技, 31(2), 4-5, 11.]

Gong B, Xia YJ, Zhang GF, Lu Y, Sun G (2012) Population structure and spatial pattern of Parrotia subaequalis, a rare and endangered species endemic to China. Journal of Ecology and Rural Environment, 28, 638-646. (in Chinese with English abstract) [龚滨, 夏洋洁, 张光富, 陆芸, 孙国 (2012) 中国特有珍稀濒危树种银缕梅种群结构和空间格 局. 生态与农村环境学报, 28, 638-646.]

Guan KL, Tao YZ (1988) Current situation and propagation of rare tree species-Ostrya rederiana. Journal of Zhejiang Forestry College, 5(1), 93-95. (in Chinese) [管康林, 陶银 周 (1988) 濒危树种——目铁木的现状和繁殖. 浙江 林学院学报, 5(1), 93-95.]

Guo XY, Wang MM, Wu JF, Wu GY, Zhang X, Huo LQ, Liu HX, Chen YH, Xie GW, Tan HB, Qiu SX (2019) Chemical constituents of the trunks and roots of Thuja sutchuenensis. Fitoterapia, 134, 264-269.

Guisan A, Tingley R, Baumgartner JB, Naujokaitis-Lewis I, Sutcliffe PR, Tulloch AIT, Regan TJ, Brotons L, McDonald-Madden E, Mantyka-Pringle C, Martin TG, Rhodes JR, Maggini R, Setterfield SA, Elith J, Schwartz MW, Wintle BA, Broennimann O, Austin M, Ferrier S,
Kearney MR, Possingham HP, Buckley YM (2013) Predicting species distributions for conservation decisions. Ecology Letters, 16, 1424-1435.

Hu BZ, Shao SL, Qian H, Zhou QZ (2004) Study on aspect and structure properties of Abies beshanzuensis. Journal of Zhejiang Forestry Science and Technology, 24(3), 12-16, 27. (in Chinese with English abstract) [胡伯智, 邵顺流, 钱 华, 周启忠 (2004) 百山祖冷杉森林植物群落的外貌与 结构特征研究. 浙江林业科技, 24(3), 12-16, 27.]

Hu YM, Fang GF, Luo XM (2011) Status of Parrotia subaequalis in taxonomy, reasons for its endangerment and protective measures. Anhui Forestry Science and Technology, 37, 46-48. (in Chinese with English abstract) [胡一民, 方国富, 骆绪美 (2011) 银缕梅的分类学地位、 濒危原因与保护对策. 安徽林业科技, 37, 46-48.]

Huang SH, Fang YM, Zhang QX, Fang SQ, Wang B, Chen H (2006) Study on cuttage propagation of Shaniodendron subaequale. Journal of Southwest Forestry College, 26(5), 94-96. (in Chinese with English abstract) [黄绍辉, 方炎明, 张启香, 方顺清, 王波, 陈花 (2006) 银缕梅扞插繁殖试 验. 西南林学院学报, 26(5), 94-96.]

Jian SG, Wu M, Liu N (2005) Genetic diversity of Cycas changjiangensis detected by allozyme analysis. Guihaia, 25, 566-569, 561. (in Chinese with English abstract) [简曙光, 吴梅, 刘念 (2005) 葫芦苏铁遗传多样性的等位酶分析. 广西植物, 25, 566-569, 561.]

Jian SG, Liu N, Gao ZZ, Wei Q, Xie ZH, Wu M, Ren H (2006) Biological characteristics of wild Cycas fairylakea population in Guangdong Province, China. Frontiers of Biology in China, 1, 430-433.

Jiang HY, Yang FS, Song XQ (2011) Preliminary study on artifical sowing of Dendrobium sinense in natural habitat in Bawangling Natural Reserve, Hainan Island. Tropical Forestry, 39(2), 40-43. (in Chinese with English abstract) [姜吴颖, 杨福孙, 宋希强 (2011) 华石斛原生境条件下 人工播种的初步探讨. 热带林业, 39(2), 40-43.]

Jin JY, Qin WG, Tan WN, Luo LJ, Qin GL (2013) Interspecific association among dominant populations in endangered plant Kmeria septentrionalis communities. Journal of West China Forestry Science, 42, 86-94. (in Chinese with English abstract) [金俊彦, 覃文更, 谭卫宁, 罗柳娟, 覃国乐 (2013) 濒危植物单性木兰群落主要种群种间联结性研 究. 西部林业科学, 42, 86-94.]

Kramer AT, Ison JL, Ashley MV, Howe HF (2008) The paradox of forest fragmentation genetics. Conservation Biology, 22, 878-885.

Lai JY, Pan CL, Qin WG , Wei GF (2007) The floral syndrome and its pollination adaptability in Kmeria septentrionalis (Magnoliaceae). Acta Botanica Yunnanica, 29, 303-308. (in Chinese with English abstract) [赖家业, 潘春柳, 覃文更, 韦国富 (2007) 单性木兰花部综合特征及其传粉适应性. 云南植物研究, 29, 303-308.]

Larkin DJ, Jacobi SK, Hipp AL, Kramer AT (2016) Keeping 
all the PIECES: Phylogenetically informed ex situ conservation of endangered species. PLoS ONE, 11, e0156973.

Li DQ (2004) Status quo \& protection countermeasure on Guangxi wild sago plam resources. Central South Forest Inventory and Planning, 23(3), 33-36. (in Chinese with English abstract) [黎德丘 (2004) 广西野生苏铁资源现状 与保护对策. 中南林业调查规划, 23(3), 33-36.]

Li HP, Yue CL, Yu QJ, Yang ZJ, Shao SL, Yu LP (2012) Advance of research on Parrotia subaequalis. Journal of Zhejiang Forestry Science and Technology, 32, 79-84. (in Chinese with English abstract) [李贺鹏, 岳春雷, 郁庆君, 杨在娟, 邵顺流, 俞立鹏 (2012) 珍稀濒危植物银缕梅的 研究进展. 浙江林业科技, 32, 79-84.]

Li WX, Xing F, Zhou YB, Guo WX, Huang YL (2019) Characterization of the complete chloroplast genome of Euryodendron excelsum (Pentaphylacaceae), a critically endangered species endemic to China. Conservation Genetics Resources, 11, 275-278.

Li XK, Su ZM, Ou ZL, Ning SJ, Tang RQ, Li RT (2002a) On intraspecific and interspecific competition among Abies yuanbaoshanensis community. Journal of Plant Resources and Environment, 11(1), 20-24. (in Chinese with English abstract) [李先琨, 苏宗明, 欧祖兰, 宁世江, 唐润琴, 李 瑞棠 (2002a) 元宝山冷杉群落种内与种间竞争的数量关 系. 植物资源与环境学报, 11(1), 20-24.]

Li XK, Su ZM, Xiang WS, Ning SJ, Tang RQ, Ou ZL, Li RT (2002b) Study on the structure and spatial pattern of the endangered plant population of Abies yuanbaoshanensis. Acta Ecologica Sinica, 22, 2246-2253. (in Chinese with English abstract) [李先琨, 苏宗明, 向悟生, 宁世江, 唐润 琴, 欧祖兰, 李瑞棠 (2002b) 濒危植物元宝山冷杉种群 结构与分布格局. 生态学报, 22, 2246-2253.]

Li XK, Xiang WS, Tang RQ (2002c) Analysis of the life table of endangered population Abies yuanbaoshanensis. Journal of Tropical and Subtropical Botany, 10(1), 9-14. (in Chinese with English abstract) [李先琨, 向悟生, 唐润琴 (2002c) 濒危植物元宝山冷杉种群生命表分析. 热带亚热 带植物学报, 10(1), 9-14.]

Li XP, Yu CY, Wu YY, Hong ZY, Sun J, Chen YP, Miao LX (2010) The biological reason for endangerment of Carpinus putoensis and measures for gene conservation. Scientia Silvae Sinicae, 46(7), 69-76. (in Chinese with English abstract) [李修鹏, 俞慈英, 吴月燕, 洪中跃, 孙晶, 陈叶 平, 缪玲霞 (2010) 普陀鹅耳枥濒危的生物学原因及基 因资源保存措施. 林业科学, 46(7), 69-76.]

Liang LL, Pan QB (2012) Current situation and protection of Abies yuanbaoshanensis. Inner Mongolia Forestry Investigation and Design, 35(4), 12-14. (in Chinese with English abstract) [梁凌林, 潘庆宝 (2012) 元宝山冷杉资 源现状及保护初探. 内蒙古林业调查设计, 35(4), 12-14.]

Liao WF, Xia NH, Deng YF, Zheng QY (2004) Study on genetic diversity of Manglietia decidua (Magnoliaceae).
Acta Botanica Yunnanica, 26, 58-64. (in Chinese with English abstract) [廖文芳, 夏念和, 邓云飞, 郑庆衍 (2004) 华木莲的遗传多样性研究. 云南植物研究, 26, 58-64.]

Lin Y, Ai XR, Yao L, Guo QJ, Zhang MX, Chen J (2017) Population structure and dynamics of Metasequoia glyptostroboides parent trees. Chinese Journal of Ecology, 36, 1531-1538. (in Chinese with English abstract) [林勇, 艾训儒, 姚兰, 郭秋菊, 张敏霞, 陈俊 (2017) 水杉原生 母树种群结构与动态. 生态学杂志, 36, 1531-1538.]

Liu J, Zhou W, Gong X (2015) Species delimitation, genetic diversity and population historical dynamics of Cycas diannanensis (Cycadaceae) occurring sympatrically in the Red River region of China. Frontiers in Plant Science, 6, 696.

Liu JF, Shi SQ, Chang EM, Yang WJ, Jiang ZP (2013) Genetic diversity of the critically endangered Thuja sutchuenensis revealed by ISSR markers and the implications for conservation. International Journal of Molecular Sciences, 14, 14860-14871.

Liu JF, Jiang ZP, Xiao WF, Wang JX (2005) A prelimiinary study on the population pattern and dynamics of critically endangered plant, Thuja sutchuenensis (Cupressaceae). Acta Agriculturae Universitatis Jiangxiensis, 27, 708-712. (in Chinese with English abstract) [刘建锋, 江泽平, 肖文发, 王建修 (2005) 极度濒危植物一一崖柏种群空间格局与 动态的初步研究. 江西农业大学学报, 27, 708-712.]

Liu JF, Xiao WF, Guo ZH, Jiang ZP, Liu ZY (2004) A preliminary study on population structure and dynamics of a rare and endangered plant, Thuja sutchuenensis (Cupressaceae). Acta Agriculturae Universitatis Jiangxiensis, 26, 377-380. (in Chinese with English abstract) [刘建锋, 肖文发, 郭志华, 江泽平, 刘正宇 (2004)珍稀濒危植物——崖柏种群结构与动态初步研究. 江西农业大学学报, 26, 377-380.]

Liu JF, Xiao WF (2008) RAPD analysis of the genetic diversity of a critically endangered plant, Thuja sutchuenensis (Cupressaceae). Acta Agriculturae Universitatis Jiangxiensis, 30, 68-72. (in Chinese with English abstract) [刘建锋, 肖文发 (2008) 濒危植物崖柏遗传多样性的 RAPD分析. 江西农业大学学报, 30, 68-72.]

Liu N, Xie JG (2007) Distribution and type locality of Cycas taiwaniana. Acta Phytotaxonomica Sinica, 45, 246-250. (in Chinese with English abstract) [刘念, 谢建光 (2007) 台湾 苏铁的分布及模式产地. 植物分类学报, 45, 246-250.]

Liu ZH, Zhang JL, Liu YH, Tang SQ (2011) Spatial pattern analysis of Abies ziyuanensis population in Dayuan. Guihaia, 31, 614-619. (in Chinese with English abstract) [刘 招辉, 张建亮, 刘燕华, 唐绍清 (2011) 大院资源冷杉种 群的空间分布格局分析. 广西植物, 31, 614-619.]

Lowe WH, Kovach RP, Allendorf FW (2017) Population genetics and demography unite ecology and evolution. Trends in Ecology \& Evolution, 32, 141-152. 
Lu SJ, Deng LL, Li XW (1999) A study on endangered causes of Pinus squamata. Journal of Northwest Forestry University, 14(1), 42-44. (in Chinese with English abstract) [陆素娟, 邓莉兰, 李乡旺 (1999) 五针白皮松濒危原因 初步研究. 西北林学院学报, 14(1), 42-44.]

Luo WH, Deng T, Zhao B, Huang SX, Tang WX (2013) Seed dormancy and germination of endangered species Cycas debaoensis. Seed, 32, 72-74. (in Chinese) [骆文华, 邓涛, 赵博, 黄仕训, 唐文秀 (2013) 濒危植物德保苏铁种子休 眠与萌发. 种子, 32, 72-74.]

Luo Y, Wu SB, Ku WP, Yang SZ, Wu JS (2018) Community structure characteristics and species diversity of rare and endangered plants of Ostrya rehderiana. Journal of Zhejiang Agricultural Sciences, 59, 2061-2064. (in Chinese) [罗远, 吴世斌, 库伟鹏, 杨淑贞, 吴家森 (2018) 珍稀濒危植物 天目铁木群落结构及物种多样性. 浙江农业科学, 59, 2061-2064.]

Ma FQ, Qin AL, Guo QS, Jian ZJ, Pei SX, Wang XF, Zhang SQ, Xing JC (2017) Geographical distribution and habitat characteristics of critically endangered species, Thuja sutchuenensis. Chinese Journal of Ecology, 36, 1777-1784. (in Chinese with English abstract) [马凡强, 秦爱丽, 郭泉 水, 简尊吉, 裴顺祥, 王祥福, 张世强, 邢继畴 (2017) 极度濒危物种崖柏的地理分布及其生境特征. 生态学杂 志, 36, 1777-1784.]

Ma XY, Jian SG, Wu M, Liu N (2003) The population characters and conservation of Cycas debaoensis Y. C. Zhong et C. J. Chen. Guihaia, 23, 123-126, 142. (in Chinese with English abstract) [马晓燕, 简曙光, 吴梅, 刘念 (2003) 德保苏铁居群特征及保护措施. 广西植物, 23, 123-126, 142.]

Ma YP, Chen G, Grumbine RE, Dao ZL, Sun WB, Guo HJ (2013) Conserving plant species with extremely small populations (PSESP) in China. Biodiversity and Conservation, 22, 803-809.

Miao SY, Tang ZX, Deng DM, Zhou JT, Pan LJ, Wang HL, Li CB, Huang FC (2013) Habital characteristics of Primulina tabacum populations in a cave at Shangbaichang, Lianzhou, Guangdong. Ecology and Environmental Sciences, 22, 554-562. (in Chinese with English abstract) [缪绅裕, 唐志 信, 邓冬梅, 周健桃, 潘丽君, 王厚麟, 李春波, 黄福长 (2013) 广东连州上柏场报春苣苔种群及其生境特征. 生 态环境学报, 22, 554-562.]

Mo NB, Xie YZ, Qin KP, Tu DH, Wang YB (2012) Traits of concomitant communities of rare and endangered plant Dayaoshania cotinifolia. Guangxi Forestry Science, 41, 242-247. (in Chinese with English abstract) [莫耐波, 谢云 珍, 覃康平, 涂德华, 王玉兵 (2012) 珍稀濒危植物瑶山 菅苔伴生群落特征. 广西林业科学, 41, 242-247.]

Ning SJ, Tang RQ (2005) A preliminary study on degenerate mechanism of the population of Abies ziyuanensis in Yinzhulaoshan, Guangxi. Guihaia, 25, 289-294, 320. (in Chinese with English abstract) [宁世江，唐润琴 (2005) 广
西银竹老山资源冷杉种群退化机制初探. 广西植物, 25, 289-294, 320.]

Ning SJ, Tang RQ, Cao JW (2005) Current status and conservation countermeasures of germplasm resources of Abies ziyuanensis. Guihaia, 25, 197-200, 280. (in Chinese with English abstract) [宁世江, 唐润琴, 曹基武 (2005) 资源冷杉现状及保护措施研究. 广西植物, 25, 197-200, 280.]

Nong A (2014) Study on protection in situ and breeding of Cycas debaoensis in Guangxi. Agriculture and Technology, 34(2), 97, 99. (in Chinese) [农安 (2014) 广西德保苏铁就 地保护与繁育研究. 农业与技术, 34(2), 97, 99.]

Nong BX, Huang YY, Liu C (2011) Genetic relationships analysis in some species of Cycas in China by RAPD markers. Guihaia, 31, 167-174, 226. (in Chinese with English abstract) [农保选, 黄玉源, 刘驰 (2011) 基于 RAPD分析的中国苏铁属部分种类亲缘关系探讨. 广西 植物, 31, 167-174, 226.]

Pan CL, Lai JY, Li XD, Shi HM (2008) Seed rain and natural regeneration of Kmeria septentrionalis in Mulun of Guangxi. Chinese Journal of Ecology, 27, 2235-2239. (in Chinese with English abstract) [潘春柳, 赖家业, 黎向东, 石海明 (2008) 单性木兰种子雨与天然更新的初步调查. 生态学杂志, 27, 2235-2239.]

Pan GB, Zhao FL (2011) Study on the geographical distribution of Cycas debaoensis in the wild and priority protected areas. Agricultural Research and Application, (4), 30-32. (in Chinese) [潘光波, 赵峰否 (2011) 野生德保苏 铁植物地理分布及优先保护区域研究. 农业研究与应用, (4), 30-32.]

Peng YH, He QF, Tan CQ, Shen WH, Qin WG, He F (2016) Quantitative analysis of stand spatial structure of a rare species Kmeria septentrionalis in Guangxi. Chinese Journal of Ecology, 35, 363-369. (in Chinese with English abstract) [彭玉华, 何琴飞, 谭长强, 申文辉, 覃文更, 何峰 (2016) 广西极小种群单性木兰群落空间结构量化. 生态学杂志, 35, 363-369.]

Peng YH, Zheng W, He QF, Shen WH, Liu J, Tan WN, He F (2015) Soil characteristics of Kmeria septentrionalis communities. Journal of Central South University of Forestry \& Technology, 35(10), 44-48. (in Chinese with English abstract) [彭玉华, 郑威, 何琴飞, 申文辉, 刘建, 谭卫宁, 何峰 (2015) 单性木兰群落的土壤特征. 中南林 业科技大学学报, 35(10), 44-48.]

Qin HN, Yang Y, Dong SY, He Q, Jia Y, Zhao LN, Yu SX, Liu HY, Liu B, Yan YH, Xiang JY, Xia NH, Peng H, Li ZY, Zhang ZX, He XJ, Yin LK, Lin YL, Liu QR, Hou YT, Liu Y, Liu QX, Cao W, Li JQ, Chen SL, Jin XH, Gao TG, Chen WL, Ma HY, Geng YY, Jin XF, Chang CY, Jiang H, Cai L, Zang CX, Wu JY, Ye JF, Lai YJ, Liu B, Lin QW, Xue NX (2017) Threatened species list of China's higher plants. Biodiversity Science, 25, 696-744. (in Chinese and in English) [覃海宁, 杨永, 董仕勇, 何强, 贾渝, 赵莉娜, 
于胜祥, 刘慧圆, 刘博, 严岳鸿, 向建英, 夏念和, 彭华, 李振宇, 张志翔, 何兴金, 尹林克, 林余霖, 刘全儒, 侯 元同, 刘演, 刘启新, 曹伟, 李建强, 陈世龙, 金效华, 高 天刚, 陈文俐, 马海英, 耿玉英, 金孝锋, 常朝阳, 蒋宏, 蔡蕾, 蔵春金金, 武建勇, 叶建飞, 赖阳均, 刘冰, 林秦文, 薛纳新 (2017) 中国高等植物受威胁物种名录. 生物多 样性, 25, 696-744.]

Qiu YJ, Yi GM, Ning ZL, Huang HW (2011) Geographic distribution, current status of resources and endangered factors of endangered plant Nothotsuga longibracteata. Journal of Plant Resources and Environment, 20, 53-59. (in Chinese with English abstract) [邱迎君, 易官美, 宁祖林, 黄宏文 (2011) 濒危植物长苞铁杉的地理分布和资源现 状及致危因素分析. 植物资源与环境学报, 20, 53-59.]

Ren H, Peng SL, Zhang DX, Jian SG, Wei Q, Zhang QM, Liu N, Li SJ, Chen WB, Zhuang YZ (2003) The ecological and biological characteristics of an endangered plant, Primulina tabacum Hance. Acta Ecologica Sinica, 23, 1012-1017. (in Chinese with English abstract) [任海, 彭少麟, 张奠湘, 简 曙光, 韦强, 张倩媚, 刘念, 李世晋, 陈文杉, 庄益智 (2003) 报春苣苔的生态生物学特征. 生态学报, 23, 1012-1017.]

Ren H, Jian SG, Liu HX, Zhang QM, Lu HF (2014) Advances in the reintroduction of rare and endangered wild plant species. Science China Life Sciences, 57, 603-609.

Ren H, Zhang QM, Lu HF, Liu HX, Guo QF, Wang J, Jian SG, Bao HO (2012) Wild plant species with extremely small populations require conservation and reintroduction in China. Ambio, 41, 913-917.

Shen SK, Ma HY, Liu XY, Wang YH (2007) The endangered causes and preserving strategies for Euryodendron excelsum, a plant endemic to China. Ecology and Environment, 16, 1819-1823. (in Chinese with English abstract) [申仕康, 马海英, 刘湘永, 王跃华 (2007) 中国 特有植物猪血木的濒危原因及保护对策. 生态环境, 16, 1819-1823.]

Shen SK, Ma HY, Wang YH, Wang BY, Shen GZ (2008) The structure and dynamics of natural population of the endangered plant Euryodendron excelsum H. T. Chang. Acta Ecologica Sinica, 28, 2404-2412. (in Chinese with English abstract) [申仕康, 马海英, 王跃华, 王博轶, 申国柱 (2008) 濒危植物 猪血木 木 (Euryodendron excelsum H.T.Chang) 自然种群结构及动态. 生态学报, 28, 2404-2412.]

Sheng QQ, Zhu ZL (2018) Photosynthetic capacity, stomatal behavior and chloroplast ultrastructure in leaves of the endangered plant Carpinus putoensis W. C. Cheng during gaseous $\mathrm{NO}_{2}$ exposure and after recovery. Forests, 9, 561.

Shi BL, Wu JS, Zhong TL (2006) Research on seed properties and germination test of six species of Acer. Journal of Zhejiang Forestry Science and Technology, 26(3), 38-40. (in Chinese with English abstract) [石柏林, 吴家森, 钟泰 林 (2006) 6种槭树属植物种子特性及其发芽试验. 浙江
林业科技, 26(3), 38-40.]

Su JY, Yan Y, Li C, Li D, Du FK (2020) Informing conservation strategies with genetic diversity in Wild Plant with Extremely Small Populations: A review on gymnosperms. Biodiversity Science, 28, 376-384. (in Chinese with English abstract) [苏金源, 燕语, 李冲, 李丹, 杜芳 (2020) 通过遗传多样性探讨极小种群野生植物的 致濒机理及保护策略: 以裸子植物为例. 生物多样性, 28, 376-384.]

Sun XL, Shi SZ, Liu ZW, Li XC, Chen Q (2019) Study on seed breeding about the endangered plant Cycas changjiangensis. Journal of Anhui Agricultural Sciences, 47, 117-119. (in Chinese with English abstract) [孙湘来, 石绍章, 刘志伟, 李小成, 陈庆 (2019) 濒危植物葫芦苏铁种子繁育技术 研究. 安徽农业科学, 47, 117-119.]

Sun YJ, Chen XX, Fu QF, Gong YQ, Kuang JH, Li N, Rong JW, Liao WB (2019) Niche characteristics of dominant species of Cycas fairylakea community in Meilin Reservoir, Shenzhen. Journal of Central South University of Forestry \& Technology, 39(11), 63-70. (in Chinese with English abstract) [孙延军, 陈晓喜, 付奇峰, 龚奕青, 广嘉慧, 李 楠, 荣建伟, 廖文波 (2019) 深圳市梅林水库仙湖苏铁群 落优势种群生态位研究. 中南林业科技大学学报, 39(11), 63-70.]

Tang RQ, Li XK, Ou ZL, Li RT (2001) The fruiting characteristics and reproductive capacity of seeds of Abies yuanbaoshanensis. Bulletin of Botanical Research, 21, 403-408. (in Chinese with English abstract) [唐润琴, 李先 琨, 欧祖兰, 李瑞棠 (2001) 濒危植物元宝山冷杉结实特 性与种子繁殖力初探. 植物研究, 21, 403-408.]

Tian K, Zhang GX, Cheng XF, He SJ, Yang YM, Yang YX (2003) The habitat fragility of Manglietiastrum sinicum. Acta Botanica Yunnanica, 25, 551-556. (in Chinese with English abstract) [田昆, 张国学, 程小放, 和世钧, 杨宇 明, 杨永兴 (2003) 木兰科濒危植物华盖木的生境脆弱 性. 云南植物研究, 25, 551-556.]

Wang DB, Ji SY, Chen FP (2009) The spatial distribution pattern of main populations in Cycas fairylakea community. Journal of Southwest China Normal University (Natural Science Edition), 34, 93-97. (in Chinese with English abstract) [汪殿蓓, 暨淑仪, 陈飞鹏 (2009) 仙湖苏铁群落 主要种群的空间分布格局. 西南师范大学学报(自然科学 版), 34, 93-97.]

Wang DB, Ji SY, Chen FP, Peng SL (2007) Age estimation and age structure of Cycas fairylakea population in Shenzhen City. Chinese Journal of Applied Ecology, 18, 476-480. (in Chinese with English abstract) [汪殿蓓, 暨淑仪, 陈飞鹏, 彭少麟 (2007) 仙湖苏铁种群年龄判断及年龄结构特征. 应用生态学报, 18, 476-480.]

Wang L, Jing HJ, Fan Q, Chen CQ, Liao WB (2013) Living situation and characteristics of the community of endangered Abies beshanzuensis var. ziyuanensis in Mount Nanfengmian of Jiangxi Province. Guihaia, 33, 651-656. (in 
Chinese with English abstract) [王蕾, 景慧娟, 凡强, 陈春 泉, 廖文波 (2013) 江西南风面濒危植物资源冷杉生存 状况及所在群落特征. 广西植物, 33, 651-656.]

Wang L, Zhao K, Ruan XD, Zhang C, Cao KB, Sun JJ (2018) Study on the population structure characteristics of the rare and endangered species Parrotia subaequalis-Taking Jinzhai County in Anhui Province as an example. Forest Resources Management, (3), 81-87. (in Chinese with English abstract) [王林, 赵凯, 阮向东, 张超, 曹科斌, 孙 晶晶 (2018) 珍稀濒危物种银缕梅种群结构特征研究 —以安徽省金寨县为例. 林业资源管理, (3), 81-87.]

Wang RY, Zhang YP, Li WQ, Lin HJ (2020) A study on the ex-situ conservation of germplasm resources of Pinus squamaia. Yunnan Nongye Keji, (2), 4-6. (in Chinese) [王 茹芸, 张玉萍, 李卫琼, 林泋君 (2020) 巧家五针松种质 资源迁地保护研究. 云南农业科技, (2), 4-6.]

Wang TX, Qi SJ, Song XQ, Meng QW, Yu XD (2018) Correlation analysis between population dynamics and reproduction strategies in Dendrobium sinense (Orchidaceae), an endemic orchid in Hainan Island. Journal of Tropical Biology, 9, 189-197. (in Chinese with English abstract) [王童欣, 戚山江, 宋希强, 孟千万, 于旭东 (2018) 华石斛种群动态与繁殖策略的相关性分析. 热带 生物学报, 9, 189-197.]

Wang X, Deng HP, Huang Q, Zhang SQ, Rao DS (2017) Flora analysis and vertical structure optimization of the community of Thuja sutchuenensis Franch. Acta Botanica Boreali-Occidentalia Sinica, 37, 181-190. (in Chinese with English abstract) [王金鍂, 邓洪平, 黄琴, 张世强, 饶东升 (2017) 崖柏群落植物区系分析及其最优垂直结构搭配探 究. 西北植物学报, 37, 181-190.]

Wang XH, Li J, Zhang LM, He ZW, Mei QM, Gong X, Jian SG (2019) Population differentiation and demographic history of the Cycas taiwaniana complex (Cycadaceae) endemic to South China as indicated by DNA sequences and Microsatellite markers. Frontiers in Genetics, 10, 1238.

Wang XM, Lai YL, Xu XM, Ying ZM, Su YJ, Li YB, Liao WB (2006) Genetic variation in the endemic plant Cycas fairylakea (Cycadaceae) from Meilin Forest Park in Shenzhen on the basis of ISSR analysis. Acta Scientiarum Naturalium Universitatis Sunyatseni, 45(3), 82-85. (in Chinese) [王晓明, 赖燕玲, 徐向明, 应站明, 苏应娟, 李 月波, 廖文波 (2006) 深圳梅林仙湖苏铁野生种群遗传 多样性ISSR分析. 中山大学学报(自然科学版), 45(3), 82-85.]

Wang XQ, Ma LY, Guo BX, Fan SH, Tan JX (2005) Analysis on the change of the original Metasequoia glyptostroboides population and its environment in Lichuan Hubei from 1948 to 2003. Acta Ecologica Sinica, 25, 972-977. (in Chinese with English abstract) [王希群, 马履一, 郭保香, 范深厚, 谭鉴锡 (2005) 湖北利川水杉原生种群及其生境1948 2003年间变化分析. 生态学报, 25, 972-977.]

Wang XQ, Zou YP, Zhang DM, Hong DY, Liu ZY (1996)
RAPD analysis of genetic diversity of Cathaya argyrophylla. Science in China (Series C), 26, 436-441. (in Chinese) [汪小全, 邹喻苹, 张大明, 洪德元, 刘正宇 (1996) 银杉遗传多样性的RAPD分析. 中国科学C辑: 生 命科学, 26, 436-441.]

Wang Y, Tang SQ, Li XK (2004) The genetic diversity of the endangered plant Abies yuanbaoshanensis. Biodiversity Science, 12, 269-273. (in Chinese with English abstract) [王 燕, 唐绍清, 李先琨 (2004) 濒危植物元宝山冷杉的遗传 多样性研究. 生物多样性, 12, 269-273.]

Wang YH, Li N, Chen T, Gong YQ (2018) Generation and characterization of expressed sequence tags (ESTs) from coralloid root cDNA library of Cycas debaoensis. Plant Diversity, 40, 245-252.

Wang YB, Liang HW, Chen FJ, Qin KP, Mo NB (2008) The endangered causes and protecting strategies for Dayaoshania cotinifolia, an endemic plant in Guangxi. Ecology and Environment, 17, 1956-1960. (in Chinese with English abstract) [王玉兵, 梁宏伟, 陈发菊, 覃康平, 莫耐 波 (2008) 广西特有植物瑶山菅苔的濒危原因及保护对 策. 生态环境, 17, 1956-1960.]

Wang Z, Hu ZY, Huang L (2015) Development and characterization of genomic microsatellite markers in Apterosperma oblata (Theaceae) and cross-amplification in Euryodendron excelsum (Ternstroemiaceae). Conservation Genetics Resources, 7, 119-120.

Wang ZL, Ding LX, Zhao MS, Cheng XY, Shen Q (2008) Genetic diversity of Ostrya rehderiana revealed by RAPD markers. Journal of Zhejiang Forestry College, 25, 304-308. (in Chinese with English abstract) [王祖良, 丁丽霞, 赵明 水, 程晓渊, 沈乾 (2008) 濒危植物天目铁木遗传多样性 的RAPD分析. 浙江林学院学报, 25, 304-308.]

Wei R, Zhang XC (2014) Rediscovery of Cystoathyrium chinense Ching (Cystopteridaceae): Phylogenetic placement of the critically endangered fern species endemic to China. Journal of Systematics and Evolution, 52, 450-457.

Wen ZY, Yu LF, Chen HL, Yang HZ, He R (2016) Investigation and niche analysis of natural Cystonathyrium chinese population in the Erlang Mountain. Journal of Sichuan Forestry Science and Technology, 37(5), 51-54, 88. (in Chinese with English abstract) [文智猷, 余凌帆, 陈洪 连, 杨洪忠, 何让 (2016) 二郎山濒危植物光叶蕨群落学 调查及生态位分析. 四川林业科技, 37(5), 51-54, 88.]

Wu ML, Yao L, Ai XR, Zhu J, Zhu Q, Wang J, Huang X, Hong JF (2020) The reproductive characteristics of core germplasm in a native Metasequoia glyptostroboides population. Biodiversity Science, 28, 303-313. (in Chinese with English abstract) [吴漫玲, 姚兰, 艾训儒, 朱江, 朱 强, 王进, 黄小, 洪建峰 (2020) 水杉原生种群核心种质 资源的繁殖特性. 生物多样性, 28, 303-313.]

Wu P, Zhang KP (2008) Status of Cycas spp. plants in Yunnan and measures for their protection. Forest Inventory and Planning, 33(4), 116-119. (in Chinese with English abstract) 
[吴萍, 张开平 (2008) 云南苏铁植物的现状及保护对策. 林业调查规划, 33(4), 116-119.]

Wu YG, Rao LB, Chen DL, Zhou RF, Ye ZL (2010) Artificial seedling-raising of Abies beshanzuensis seed. Journal of Anhui Agricultural Sciences, 38, 12038-12039, 12098. (in Chinese with English abstract) [吴友贵, 饶龙兵, 陈德良, 周荣飞, 叶珍林 (2010) 百山祖冷杉种子的人工育苗试 验. 安徽农业科学, 38, 12038-12039, 12098.]

Wu YP, Hou ZQ, Chen ZH, Xiao SY, Ma CC, Du F (2015) The resources and distribution of Nyssa yunnanensis. Journal of West China Forestry Science, 44(6), 26-30. (in Chinese with English abstract) [吴娅萍, 侯昭强, 陈中华, 肖思烨, 马晨晨, 杜凡 (2015) 云南蓝果树的种群资源及 分布现状. 西部林业科学, 44(6), 26-30.]

Xiao ZC, Gao HD (2008) Study on seed dormancy and germination properties of Acer buergerianum Miq. Journal of Southwest Forestry College, 28(5), 35-38. (in Chinese with English abstract) [肖志成, 高捍东 (2008) 三角棫种 子休眠与萌发特性研究. 西南林学院学报, 28(5), 35-38.]

Xie ZQ (1999) Gap-regeneration of Cathaya argyrophylla forests. Acta Ecologica Sinica, 19, 775-779. (in Chinese with English abstract) [谢宗强 (1999) 银杉 (Cathaya argyrophylla)林林窗更新的研究. 生态学报, 19, 775-779.]

Xie ZQ, Chen WL (1994) The present status and the future of Cathaya argyrophylla forest. Chinese Biodiversity, 2, 11-15. (in Chinese with English abstract) [谢宗强, 陈伟烈 (1994) 中国特有植物银杉林的现状和未来. 生物多样性, 2, 11-15.]

Xie ZQ, Chen WL (1999a) Characteristics and succession of the communities of Cathaya argyrophylla, an endangered plant. Acta Phytoecologica Sinica, 23, 48-55. (in Chinese with English abstract) [谢宗强, 陈伟烈 (1999a) 濒危植物 银杉的群落特征及其演替趋势. 植物生态学报, 23 , 48-55.]

Xie ZQ, Chen WL (1999b) The endangering causes and preserving strategies for Cathaya argyrophylla, a plant endemic to China. Acta Phytoecologica Sinica, 23, 1-7. (in Chinese with English abstract) [谢宗强, 陈伟烈 (1999b) 中国特有植物银杉的濒危原因及保护对策. 植物生态学 报, 23, 1-7.]

Xie ZQ, Chen WL, Hu D, Zhu RG (1998) The fruiting characteristics of an endangered plant, Cathaya argyrophylla and the impact of animals on fruits. Acta Phytoecologica Sinica, 22, 319-326. (in Chinese with English abstract) [谢宗强, 陈伟烈, 胡东, 朱日光 (1998) 濒危植物银杉的结实特性及动物对果实的危害性. 植物 生态学报, 22, 319-326.]

Xie ZQ, Chen WL, Liu ZY, Jiang MX, Huang HD (1999a) Spiatial distribution pattern of Cathaya argyrophylla population. Acta Botanica Sinica, 41, 95-101. (in Chinese with English abstract) [谢宗强, 陈伟烈, 刘正宇, 江明喜, 黄汉东 (1999a) 银杉种群的空间分布格局. 植物学报, 41, 95-101.]
Xie ZQ, Chen WL, Lu P, Hu D (1999b) The demography and age structure of the endangered plant population of Cathaya argyrophylla. Acta Ecologica Sinica, 19, 523-528. (in Chinese with English abstract) [谢宗强, 陈伟烈, 路鹏, 胡 东 (1999b) 濒危植物银杉的种群统计与年龄结构. 生态 学报, 19, 523-528.]

Xie ZQ, Li QM (2000) Seed characteristics of endangered plant Cathaya argyrophylla. Acta Phytoecologica Sinica, 24, 82-86. (in Chinese with English abstract) [谢宗强, 李庆梅 (2000) 濒危植物银杉种子特性的研究. 植物生态学报, 24, 82-86.]

Xiong B, Ai XR, Wang BQ, Yi YM, Yao L, Fan SH (2010) Study on the population of the primary Metasequoia glyptostroboides mother trees. Journal of Hubei University for Nationalities (Natural Science Edition), 28, 282-285. (in Chinese with English abstract) [熊彪, 艾训儒, 王柏泉, 易 咏梅, 姚兰, 范深厚 (2010) 水杉原生母树种群研究. 湖 北民族学院学报(自然科学版), 28, 282-285.]

Xu G, Tang W, Skelley P, Liu N, Rich S (2015) Cycadophila, a new genus (Coleoptera: Erotylidae: Pharaxonothinae) inhabiting Cycas debaoensis (Cycadaceae) in Asia. Zootaxa, 3986, 251-278.

Xu XL, Jin HX, Chen XB, Jiang SL, Wang DL, Guo YF (2012) Biological characteristics of the seed in Acer yanjuechi, an endangered species. Journal of Forestry Engineering, 26, 46-49. (in Chinese with English abstract) [许小连, 金荷仙, 陈香波, 江胜利, 王东良, 郭要福 (2012) 濒危树种羊角 槭种子基本生物学特征. 林业科技开发, 26, 46-49.]

Yang J, Ding T, Jiang RH, Wang YR, Xiang QP (2019) The complete chloroplast genome of the Abies yuanbaoshanensis, an endangered Pinaceae species in Southern China. Mitochondrial DNA Part B, 4, 3386-3387.

Yang J, Cai L, Liu DT, Chen G, Gratzfeld J, Sun WB (2020) China's conservation program on Plant Species with Extremely Small Populations (PSESP): Progress and perspectives. Biological Conservation, 244, 108535.

Yang QP, Xiao ZY, Hu XD, Ouyang M, Chen X, Lin GJ, Xu JW, Yang GY (2017) Endangered mechanisms of Sinomanglietia glauca: Exploring and prospect. Guihaia, 37, 653-660. (in Chinese with English abstract) [杨清培, 肖智 勇, 胡晓东, 欧阳明, 陈听, 林国江, 徐佳文, 杨光耀 (2017) 珍稀植物华木莲的现代濒危机制: 探析与展望. 广西植物, 37, 653-660.]

Yang XC, Yang YT, Kang MH, Guo XY, Ma T, Xi ZX (2019) The complete plastome of Nyssa yunnanensis, a critically endangered tree species. Conservation Genetics Resources, 11, 313-315.

Ye SC (2019) Establishment and protection of Shaniodendron subaequalis'germplasm bank in Wanfo Mountain. Journal of Anhui Agricultural Sciences, 47, 120-122. (in Chinese with English abstract) [叶少川 (2019) 万佛山银缕梅种质 资源库建设及保护. 安徽农业科学, 47, 120-122.]

Yang YZ, Ma T, Wang ZF, Lu ZQ, Li Y, Fu CX, Chen XY, 
Zhao MS, Olson MS, Liu JQ (2018) Genomic effects of population collapse in a critically endangered ironwood tree Ostrya rehderiana. Nature Communications, 9, 5449.

Yuan BR (2005) Endangered mechanism and protection measures of Manglietia decidua. Jiangxi Forestry Science and Technology, 33(3), 45, 61. (in Chinese with English abstract) [袁斌荣 (2005) 落叶木莲的濒危机理与保护对 策. 江西林业科技, 33(3), 45, 61.]

Yuan YJ (2009) Wooden canopy to protect the survival of the status quo and its countermeasures. Modern Agricultural Sciences, 16, 132-133. (in Chinese with English abstract) [袁永俊 (2009) 华盖木生存现状及其保护对策. 现代农 业科学, 16, 132-133.]

Yu DP, Li CH, Ding J, Xie KP, Zhang GZ, Li SL (2011) Preliminary report on character of seed and seed culture in virto of Parakmeria omeiensis Cheng. Resource Development \& Market, 27, 197-198, 290. (in Chinese with English abstract) [余道平, 李策宏, 丁健, 谢孔平, 张国 珍, 李世丽 (2011) 峨眉拟单性木兰种子特性及离体培 养初报. 资源开发与市场, 27, 197-198, 290.]

Yu DP, Li CH, Wen XY, Li XJ, Peng QX, Xie KP (2019) Flowering biological characteristics and breeding system of Parakmeria omeiensis. Guihaia, 39, 600-607. (in Chinese with English abstract) [余道平, 李策宏, 文香英, 李小杰, 彭启新, 谢孔平 (2019) 峨眉拟单性木兰的开花生物学 特性与繁育系统. 广西植物, 39, 600-607.]

Yu LF, Gao J, He R, Du JJ, You JY, Deng DZ (2015) Discussion on investigations of the present status of Cystoathyrium chinensis resources in Tianquan and protection measures. Journal of Sichuan Forestry Science and Technology, 36(3), 120-124, 17. (in Chinese with English abstract) [余凌帆, 高健, 何让, 杜俊杰, 尤继勇, 邓东周 (2015) 天全县光叶蕨资源现状调查与保护对策 研讨. 四川林业科技, 36(3), 120-124, 17.]

Yu ZX, Liao J, Lin XC, Zheng QY, Zhang JP, Qiu LH, Li ZQ, Xiao GM (1999) Ecological study on communities of Manglietia decidua. Acta Agriculturae Universitatis Jiangxiensis, 21(2), 73-77. (in Chinese with English abstract) [俞志雄, 廖军, 林新春, 郑庆衍, 张津平, 装利 洪, 李志强, 肖国民 (1999) 华木莲植物群落的生态学研 究. 江西农业大学学报, 21(2), 73-77.]

Zang RG, Dong M, Li JQ, Chen XY, Zeng SJ, Jiang MX, Li ZQ, Huang JH (2016) Conservation and restoration for typical critically endangered Wild Plants with Extremely Small Population. Acta Ecologica Sinica, 36, 7130-7135. (in Chinese with English abstract) [喊润国, 董鸣, 李俊清, 陈小勇, 曾宋君, 江明喜, 李镇清, 黄继红 (2016) 典型 极小种群野生植物保护与恢复技术研究. 生态学报, 36, 7130-7135.]

Zhan P, Xu WJ, Chen JN, Zhang L, Tan YW, Shi W (2013) Analysis of growth and genetic diversity of Manglietia deciduas in Xiaoxi National Nature Reserve. Hunan Forestry Science \& Technology, 40, 57-60. (in Chinese with
English abstract) [詹鹏, 徐万吉, 陈介南, 张林, 谭亦文, 石旺 (2013) 小溪国家级自然保护区落叶木莲生长与遗 传多样性分析. 湖南林业科技, 40, 57-60.]

Zhan QQ, Wang JF, Gong X, Peng H (2011) Patterns of chloroplast DNA variation in Cycas debaoensis (Cycadaceae): Conservation implications. Conservation Genetics, 12, 959-970.

Zhang GF, Yao R, Jiang YQ, Chen FC, Zhang WY (2016) Intraspecific and interspecific competition intensity of Parrotia subaequalis in different habitats from Wanfoshan Nature Reserve, Anhui Province. Chinese Journal of Ecology, 35, 1744-1750. (in Chinese with English abstract) [张光富, 姚锐, 蒋悦茜, 陈福程, 张文燕 (2016) 安徽万 佛山不同生境下银缕梅的种内与种间竞争强度. 生态学 杂志, 35, 1744-1750.]

Zhang RB, Dou QL, He P, Deng HP (2007) Analysis of genetic diversity in Thuja sutchuenensis populations as revealed by morphological and molecular data. Guihaia, 27, 687-691. (in Chinese with English abstract) [张仁波, 窦全丽, 何平, 邓洪平 (2007) 濒危植物崖柏遗传多样性研究. 广西植 物, 27, 687-691.]

Zhang SS, Kang HM, Yang WZ (2019) Population genetic analysis of Nyssa yunnanensis by reduced-representation sequencing technique. Bulletin of Botanical Research, 39, 899-907. (in Chinese with English abstract) [张珊珊, 康洪 梅, 杨文忠 (2019) 基于简化基因组技术的云南蓝果树 群体遗传分析. 植物研究, 39, 899-907.]

Zhang SS, Xiang ZY, Kang HM, Yang WZ (2014) Autotoxicity of Nyssa yunnanensis on seed germination and seedling growth. Forest Research, 27, 502-507. (in Chinese with English abstract) [张珊珊, 向振勇, 康洪梅, 杨文忠 (2014) 云南蓝果树对种子萌发及幼苗生长的自毒效应. 林业科学研究, 27, 502-507.]

Zhang WH, Zu YG, Liu GB (2002) Population ecological characteristics and analysis on endangered cause of ten endangered plant species. Acta Ecologica Sinica, 22, 1512-1520. (in Chinese with English abstract) [张文辉, 祖 元刚, 刘国涁 (2002) 十种濒危植物的种群生态学特征 及致危因素分析. 生态学报, 22, 1512-1520.]

Zhang XH, Li XP, Yu CY, Miao LX, Chen YP (2011a) Current preservation situation and countermeasures on germplasm resources of endangered plant Carpinus putoensis Cheng. Journal of Zhejiang Ocean University (Natural Science), 30, 163-167. (in Chinese with English abstract) [张晓华, 李修 鹏, 俞慈英, 缪玲霞, 陈叶平 (2011a) 濒危植物普陀鹅耳 枥种质资源保存现状与对策. 浙江海洋学院学报(自然科 学版), 30, 163-167.]

Zhang XH, Wang ZJ, Li XP, Yu CY, Chen YP (2011b) RAPD analysis of genetic diversity of different progenies from endangered plant Carpinus putoensis. Shandong Forestry Science and Technology, 41(1), 1-5, 22. (in Chinese with English abstract) [张晓华, 王正加, 李修鹏, 俞慈英, 陈叶 平 (2011b) 濒危植物普陀鹅耳枥亲子代遗传多样性的 
RAPD分析. 山东林业科技, 41(1), 1-5, 22.]

Zhang YR (2009) Studies on Endangered Mechanism and Population Conservation of Abies ziyuanensis. $\mathrm{PhD}$ dissertation, Beijing Forestry University, Beijing. (in Chinese with English abstract) [张玉荣 (2009) 资源冷杉 的濒危机制与种群保育研究. 博士学位论文. 北京林业 大学, 北京.]

Zhang YR, Luo JC, Yu JX (2007) Genetic diversity of the endangered plant Abies ziyuanensis detected by ISSR markers. Journal of Beijing Forestry University, 29(6), 41-46. (in Chinese with English abstract) [张玉荣, 罗菊春, 喻锦秀 (2007) 资源冷杉遗传多样性的ISSR分析. 北京 林业大学学报, 29(6), 41-46.]

Zhang ZJ, Guo YP, He JS, Tang ZY (2018) Conservation status of wild plant species with extremely small populations in China. Biodiversity Science, 26, 572-577. (in Chinese with English abstract) [张则瑾, 郭炎培, 贺金生, 唐志尧 (2018) 中国极小种群野生植物的保护现状评估. 生物多 样性, 26, 572-577.]

Zhang ZY, Chen YY, Li DZ (2005) Detection of low genetic variation in a critically endangered Chinese pine, Pinus squamata, using RAPD and ISSR markers. Biochemical Genetics, 43, 239-249.

Zhao Y (2018) Reproduction and afforestation techniques of Metasequoia glyptostroboides. Xiandai Nongcun Keji, (6), 39-40. (in Chinese) [赵燕 (2018) 水杉繁殖及造林技术. 现代农村科技, (6), 39-40.]

Zheng Y, Liu J, Feng XY, Gong X (2017) The distribution, diversity, and conservation status of Cycas in China. Ecology and Evolution, 7, 3212-3224.
Zheng YL, Sun WB, Zhao XF (2008) Seed dormancy and germination of Manglietiastrum sinicum Law, a globally critical endangered plant in China. Plant Physiology Communications, 44(1), 100-102. (in Chinese with English abstract) [郑艳玲, 孙卫邦, 赵兴峰 (2008) 极度濒危植物 华盖木的种子休眠与萌发. 植物生理学通讯, 44(1), 100-102.]

Zhu L, Guo QS, Zhu NN, Qin AL, Xu GX, Xing JC (2014) Study on the cones and seeds biological characteristic of a critically endangered species, Thuja sutchuenensis, in the world. Seed, 33(7), 56-59, 63. (in Chinese) [朱莉, 郭泉水, 朱妮妮, 秦爱丽, 许格希, 邢继畴 (2014) 世界级极危物 种——崖柏的球果和种子性状研究. 种子, 33(7), 56-59, 63.]

Zhu YX, Peng C, Yu S, Hu JF, Li JY (2019) Aflatoxins from the endophytic fungus Aspergillus sp. Y-2 isolated from the critically endangered conifer Abies beshanzuensis. Natural Product Research, doi: 10.1080/14786419.2019.1696328.

Zhu YY, Xu XT (2019) Effects of climate change on the distribution of wild population of Metasequoia glyptostroboides, an endangered and endemic species in China. Chinese Journal of Ecology, 38, 1629-1636. (in Chinese with English abstract) [朱莹芗, 徐晓婷 (2019) 气 候变化对我国特有濒危物种水杉野生种群分布的影响. 生态学杂志, 38, 1629-1636.]

(责任编委：㶓润国＼cjkstart责任编辑：黄祥忠) 